\title{
ACADEMIC FREEDOM IN THE UNITED STATES
}

\author{
ERNEST VAN DEN HAaG*
}

I

\section{Academic Freedom as a Professorial Privilege}

In Europe, academic freedom usually protected the whole campus from ecclesiastical and government interference. On many campuses police were not allowed without academic consent. This extensive protection was needed, for neither professors nor students were guaranteed freedom as subjects of church and state. Yet the function of the university requires that professors be free to form and profess independent views, and students to learn from them. Hence the privilege of academic freedom.

In the United States, freedom is not an academic privilege; it is a right constitutionally guaranteed to all residents. Academic freedom is needed exclusively to protect the independence of professors from trustees, colleagues, administrators, students, alumni, and public opinion. Thus academic freedom in the United States is an intra-academic privilege which secures the independence of professors as employees, so that they may perform their professional tasks. ${ }^{1}$

The immunities which constitute academic freedom go beyond those required by the American Constitution as do the qualifications and obligations of faculty members. Extra-constitutional obligations and privileges, of course, inhere in employment and in professional status. There is no constitutional obligation to sell brushes, or fill teeth. Salesmen and dentists waive their constitutional right not to do so. On the other hand, there is no constitutional right to extract appendices or electrocute people. Physicians and executioners are granted these privileges in view of special qualifications and employments. Academic freedom is an analogous extra-constitutional privilege granted no longer to, but by, institutions of higher learning to their researchers and instructors. There is no constitutional right to university employment. Academic freedom is an extra-constitutional, intra-academic privilege which protects professors not against legal punishment but against threats of dismissal arising from the fulfillment of their duty to form and profess their views independently.

Students benefit from the academic freedom of the faculty and perhaps from the atmosphere of freedom which should prevail on a campus. So does society at large. However, students do not have academic freedom. Controversial student activities may be permitted on educational grounds (or expediency: prohibition may be more harmful than permission), on grounds of wisdom, or as a general university policy (the "or" is not necessarily disjunctive) -but academic freedom is not involved.

- M.A. 1942, State University of Iowa; Ph.D. 1952, New York University. Adjunct Professor of Social Philosophy, New York University; lecturer, The New School for Social Research.

I I am aware of occasional extra-academic pressures. But they are effective only if the university authorities are willing to translate them into internal pressure. 
Just as law or medical students may one day share the privileges of the profession they are preparing to enter, so other students may, if they become instructors, share the privileges of the faculty. As students, they do not. Unless delegated, the privilege of inviting speakers to the campus is vested in the faculty and administration, not in the students. They are members of the academic family-but it is the faculty that stands in loco parentis.

Teachers in secondary and primary schools, deans, janitors, editors, and administrators all are as free as the constitution and their employment contracts make them, but they do not have academic freedom. For this privilege is meant to secure the independence of scholars, presumed to be qualified to do their own research and teach what they have found. Teachers in secondary and primary schools are not hired to conduct research and need not be qualified to do so. Their major task is to transmit received knowledge as prescribed by the curriculum. I should urge increasing their freedom to decide what to teach, when, and how. I think it likely that teachers free to express competent opinions will be better teachers. But these are matters of expediency and educational effectiveness, not claims to academic freedom. Teachers have no such claim either historically or as a professional requirement. A modicum of employment security is probably as helpful for teachers as it is to other occupations. But only scholars need academic freedom to fulfill their professional obligations.

The qualifications of scholars are recognized in the main by other scholars. Usually the primary and frequently the decisive recommendation for employment or promotion is made by the departments familiar with the candidate's scholarly work, and passed upon by a variety of university authorities. The candidate's qualifications generally include competence in specific fields, general intelligence, a warranted belief that he will contribute to human knowledge, honesty, independence, and perhaps discretion. These qualifications pertain to academic employment as does academic freedom. Citizens are allowed to lie (except under oath); and to plagiarize works in the public domain; and to believe that W. A. Mozart discovered America, and Lysenko the inheritance of acquired characteristics. But academic employment, protected by academic freedom, requires competence and the waiver of the exercise of the constitutional rights to foolishness, ignorance, or deceptiveness (at least to some degree), and, finally, the assumption of extra-constitutional duties.

It is easier to describe the qualifications for academic employment than to positively establish their presence. They are not measurable. Disqualifications are more easily established. Mediocrity usually does best. ${ }^{2}$ The practical effects of

\footnotetext{
${ }^{2}$ Max Planck commented, on the reception of his Ph.D. thesis at the University of Munich in 1879 : "I found no interest, let alone approval, even among the very scientists who were closely related to the topic. ..." Quoted by Leo Rosten in The Creative Idea, 64 TEAchers College Record, 637, 64I (I963). (His thesis contained highly original, important, and often correct propositions.) New idcas, and those who profess them, are usually received coldly. Tycho Brahe never ceased opposing Copernicus; and the history of science discloses that originality is seldom well received. Certainly the system by which we establish qualifications for professorships is very bad-but it is the best devised so far.
} 
academic freedom-increased job security-protect incompetents and competents alike once they have acquired tenure. ${ }^{3}$ Since attempts to make it easier to get rid of incompetents make it easier also to dismiss competent professors, the net effects are unlikely to be desirable-the protection of incompetents is an unavoidable cost of academic freedom. Another objection to academic freedom is that professors who instead of teaching the "right," "good," and "true" teach "wrong," "wicked," and "untrue" ideas are protected as well. Yet someone has to decide what is "right," "good," or "true." The members of the faculty do. And there is no reason to believe that an outside authority would know or do better-or would be less vulnerable to the accusation of heresy. Indeed, one may define academic freedom as a system that locates in the faculty the main power to decide what is "right," "good," and "true" enough to be taught." Where an outside body has this power, academic freedom is limited de facto by the tolerance of this outside authority; de iure it does not exist.

\section{II}

\section{The Extent of Protection}

Not only is it hard to establish in practical terms who qualifies for it-the notion of academic freedom itself leaves some areas vague. Are utterances outside one's special field of competence protected, and outside the academic context (e.g., in a letter to newspapers)? To what extent can the university insist on honesty in matters not directly relevant to academic tasks, and on discretion, and what about rules of personal conduct?

I am inclined to hold that academic freedom should protect a professor even when he comments on matters outside his special field, and regardless of context. Else the effect of academic employment would be severely, undesirably, and unnecessarily restrictive. Yet it is hard to see how the exercise of the professor's right to free speech could be inconsistent with his academic duties.

It follows that a professor of chemistry is entitled to profess heterodox views on religious, political, or sexual matters. However much these views displease the university, he cannot be dismissed for professing them, unless he does so in the classroom instead of teaching chemistry. (But in this case he might be fired even if he professed orthodox views.) Needless to say, academic freedom automatically protects a psychologist who expresses dissident views on sexual matters or a social scientist who expresses dissident views on social matters, whether in the course of his teaching or not. The chemistry professor need not renounce his rights as a citizen; the psychologist or social scientist is protected in professing his professional views. All, however, would violate their academic duties if they were to use their positions

8 Though less strong, academic freedom resembles the protection of the judiciary but not that of civil servants. The latter are protected for the sake of efficiency and personal security, whereas academic freedom aims at protecting independence.

This power must be largely, though not exclusively, in the hands of the individual members of the faculty, rather than the body as a whole. 
to recruit for the practice of particular beliefs, or for organizations favoring them. (And that violation is most likely to be noted ceteris paribus if the belief is heterodox.) And all may be expected to exercise reasonable caution in not associating the university with their personal views.

Thus, prima facie academic freedom was violated if, as the newspapers had it, the University of Illinois fired an instructor in 1960 because he expressed unorthodox views on sex in a letter to the student paper. Mr. Leo Koch's shopworn utopia scarcely commands sympathy. (He proposed reducing extra-marital sexual relations among students to cathartic gymnastics drearily-but sanitarily-performed under university auspices.) Yet he would not have been dismissed had he expressed himself in favor of pre-marital chastity. Thus he was fired for professing dissident views. Academic freedom was violated. ${ }^{4 a}$

A case for the dismissal could be made in terms of lack of discretion. Mr. Koch must have known that in the United States universities are to some extent custodial institutions; at the least, they take some responsibility not only for scholarship and intellectual matters but also for the conduct and the morality of students. His letter to a student paper might well be understood by students, and more likely by their parents, as an authoritative expression of proposed university educational policy. Never mind that it was not meant that way. Mr. Koch should have foreseen the potential harm his letter would cause the university - a harm clearly not offset by any potential scientific or practical merit. If he was unable to understand these likely effects, or deliberately disregarded them, he might not be intelligent enough or discreet enough for his position. A case may be made along these lines. But it does not seem strong enough to justify dismissal out of hand.

\section{III}

\section{The Precartousness of Protection}

Mr. Koch's dismissal is interesting because it suggests the vulnerability of American universities, and the consequent precariousness of the academic freedom they grant. Unlike European institutions, American universities have a strong inclination to expand. They depend, therefore, on an ever increasing student body, and on ever increasing grants of money from ever increasing numbers of donors. Hence American universities tend to cater to prospective donors-more specifically state legislatures, alumni, wealthy persons, and students-far more than European universities. Administrators will hesitate to permit anything that might reduce public support and therewith the expansion potential of the university. The very fact that in American universities ultimate power is vested largely in trustees and administrators-usually representatives of the extra-academic world-rather than in faculties causes academic freedom to be a grant by these powers to the faculty, and not a part of the faculties' self-regulation, as it is in Europe.

${ }^{4 a}$ Koch v. Board of Trustees of the University of Illinois, 39 Ill. App. 51, 187 N.E.2d 340 (1963). 
The perfect solution of this problem would be an institution that manages to live on its permanent endowment. Yet, the less than perfect solution of the problem that is actually practiced-largely reliance on a multiplicity of money sources-seems to have impaired academic freedom very little.

The idea that government financing is particularly dangerous is certainly not borne out by the European experience. And in America, a government financed judiciary is quite independent-particularly when life tenure is assured.

The main danger to academic freedom is not actual outside interference, but an inside desire to please, motivated in part by the actual or presumed need of the institution for the good opinion of those who might support it financially. In the United States, neither people nor institutions like to be out of step with public opinion. Universities thus care for their public image; and departments, and professors, for popularity. This tendency, too, may lend support to restrictions and violations of the academic freedom of those who might exercise it to profess views that-however legitimate--do impair the institutions' "public relations."

Certainly restriction of academic freedom cannot be measured by the number of cases publicly debated. Prevenient restriction-the semiconscious adoption by professors, chairmen, and administrators of standards they believe will not offend public opinion-is probably more important, and it is not measurable. ${ }^{5}$ Prevenient restriction, which makes selection and promotion depend on criteria other than professional qualifications-all too often on conformity to current academic or social fashions-has restricted academic freedom far more than formal outside threats to it.

IV

\section{Communists}

Does academic freedom require or permit the dismissal of faculty members who are also communists? Those who favor retention argue that academic freedom permits dismissal only when a violation of standards of honesty or competence can be shown to have been committed by the communist faculty member. The argument takes various forms.

Sometimes it is argued that to dismiss a man merely because he is a communist abridges his right, as a citizen, to be one. But the question is not whether he can be a communist and a citizen but whether he can be a communist and a faculty member. As has been noted, what is allowed to the citizen may disqualify the faculty member. Another argument holds that to expel communists without a showing of specific violations is to regard them as guilty by association. However, communists are people who-whether they associate with other communists or not-are committed

\footnotetext{
'In Paul F. Lazarsfeld \& Wagner Thielens, JR., The Academic Mind (1958), the authors attempted to measure something of the kind during the McCarthy episode. In my judgment, they failed. (See van den Haag, Book Review, McCarthyism and the Professors, Commentary, Feb. 1959, p. I79). They didn't establish whether there was an actual increase of restriction, or of fear of restriction; nor did they find out whether professors were more fearful than usual, and if so, whether this was due to more actual danger or to more sensitivity to it, or to more anxiety otherwise generated.
} 
to sharing the aims of the Communist Party and to follow its instructions. It is not their associations, but this commitment, which is questionable.

Similarly, it is argued that even a communist must be regarded as innocent until proven guilty of specific violations. But procedures with regard to the retention of employees or members of the scholarly community cannot be analogous to those of criminal law. The criminal law looks backward. A man is guilty if he has violated the law-regardless of his future promise; and he is innocent if he cannot be demonstrated to have violated the law in the past, regardless of how well we know that he will do so in the future. But employment is concerned with the future. The past is relevant only in as much as we can infer from it upon the future. A commitment to violate academic standards in the future would be more relevant than any past action.

The legal analogy for dismissal proceedings, which is not found in criminal courts, might be sought in the procedures used to establish cause for legal separation, or annulment of marriage. (However, university authorities cannot proceed quite like a court, for they lack its power; they do not dispose of police and cannot subpoena witnesses or compel sworn testimony.) Suppose a husband has committed his affections outside of wedlock. Letters to his mistress are found, assuring her of his total devotion and promising to follow her instructions for adultery and for poisoning his wife. The husband admits the correspondence and refuses to give up his mistress. But he protests that he has not been proven guilty except by association; he has not been caught in the act of poisoning, nor is the correspondence sufficient proof that his relations with the other woman are not platonic. Thus, he maintains, separation would be undue punishment, for his wife keeps him in comfort while the mistress has no money.

A court might find the evidence insufficient to establish criminal guilt. ${ }^{B}$ But can one doubt that a separation would be granted? Yet, whether devotion to one woman excludes or even diminishes devotion for another, whether a mistress is compatible with marriage depends in practice on the personalities and social conditions of those involved. But that commitment to independence and surrender of independence are mutually exclusive is not open or dependent on social conditioning.

Since academic freedom is a promise not to dismiss professors for forming and professing independent views, it presumes that the professors themselves are committed to form and profess their views independently. But communists are committed not to. They claim academic freedom only to protect their own surrender of it. That much is no longer open to doubt." But many professors doubt that it suffices to dismiss the communists among them.

- Actually, to find a party guilty in a divorce proceeding, no court requires more than that the party be shown to have been in a highly compromising situation; proof of unfaithfulness beyond this is not required, proof of the present intent and opportunity being sufficient.

'See Sidney Hook, Heresy, Yes-Conspiracy, Nol (1953); Hook, The Ethics of Academic Freedom, in Academic Freedom, Logic, and Religion 19 (Am. Philosophical Ass'n, 1953); Hook, Indoctrination and Academic Freedom, The New Leader, March 9, I953, p. 2; Hook, Freedom in American Culture, id., 
Professor Fritz Machlup, a brilliant economist and a convinced libertarian, correctly points out that the obligation of professors is "to search for truth and speak the truth as they see it." But he does not see that this obligation is incompatible with commitments such as to "at all times take a position on every question that is in line with the policies of the party," "to take advantage of their position without exposing themselves,"10 to "display thorough readiness to accept party discipline,"11 "to carry out orders,",12 to "carry out all decisions of the party,"13 and to "skillfully inject [the party-line] into their teaching at the least risk of exposure."14

Now, these commitments, which in practice involve commitments to recruit, to spy, to recruit spies, to help promote other party members and to hinder party opponents regardless of academic merits, seem clearly incompatible with academic office. However, Machlup insists "... we cannot make party membership a decisive criterion." ${ }^{15}$ Rather we have to demonstrate that these communist commitments were actually carried out, or, at least, that the party member committed himself knowingly. This idea seems based once more on an erroneous identification of criteria of criminal justice with criteria for professional or employment disqualification.

Moreover, the kind of evidence Machlup requires to dismiss a communist could not be obtained without actually impairing academic freedom: one would have to send spies to the classroom or ask students to tell whether the professor has engaged in communist activities. (I'd rather not.) Yet the commitment to do so seems quite enough : a bank cashier who joins a gang of bank robbers and promises to follow the orders of the gang leader and help rob his bank as soon as feasible, certainly need not be retained, even if he has not, or not yet, carried out his commitment. ${ }^{16}$

To commit oneself to surrender one's independence is ipso facto to disqualify oneself for academic office. To do so without having carried out the commitment, or having been shown to have done so, certainly does not justify confidence in the future action of the communist professor. And it is the future that we are concerned with. He may lack courage or opportunity to carry out his party obligation and

April 6, I953, p. S2; Hook, Logic and the Fifth Amendment, id., Oct. I, 1956, p. 12; Hook, Ethics and the Fifth Amendment, id., Oct. 15, 1956, p. 16; van den Haag, The Communist Teacher Can't Be Free, id., May 25, 1953, p. 12; van den Haag, Academic Freedom and Its Defense, in Strengthening Education at All Levels I4 (Am. Council on Education, 1953); van den Haag, Student LoyaltyShould It Be Questioned? Yes, The New Leader, Feb. 2, r96o, p. I6.

- Academic Freedom, Time, May 10, 1963, pp. 71, 73.

- Resolution, gth Convention, Communist Party U.S.A. (I936).

${ }^{10}$ The Communist, May I937, p. 63.

${ }^{21}$ Id., Sept. 1938 , p. 808 .

${ }^{22}$ See testimony of Earl Browder in Hearings Before the House Special Committee on Un-American Activities on Investigation of Un-American Propaganda Activities in the United States. 76th Cong., Ist Sess. 4417 (1939).

${ }^{10} \mathrm{Ibid}$.

1" The Communist, supra note Io.

10 Time, May 10, 1963, p. 73.

${ }^{10}$ It seems to me that his mere refusal to repudiate the gang and to help the authorities apprehend it, raises doubts as to his fitness to remain a bank cashier. 
violate his academic one; or perhaps he did carry out party instructions so well and secretly that he cannot be shown to have done so. At any rate, having committed himself to violate academic standards appears decisive to me, regardless of the professor's skill, ability, or courage in carrying out his commitment and the presence or lack of opportunity to do so.

Perhaps some professorial party members did not fully realize what they were committing themselves to. They lacked mens rea. This keeps a man out of jail (though the question of culpable neglect may be raised). But it disqualifies him from academic employment: a man who commits himself in such a matter without knowing or finding out what he is doing is too ignorant, irresponsible, or stupid to instruct students. ${ }^{17}$

Professors, like anyone else, may be intellectually committed to such beliefs as Presbyterianism, atheism, Roman Catholicism, ${ }^{18}$ Republicanism, liberalism, conservatism, vegetarianism, idealism, materialism, pluralism, or absolutism. Such beliefs do not disqualify them as professors so long as no commitment to follow orders, recruit, or misuse their office-in short give up their independent research in favor of a party line-is involved. It is their commitment to give up their independence that disqualifies communists, and it disqualifies them regardless of their academic specialization, for they are committed to misuse any academic office.

It is sometimes argued that we can rely on the good sense of students and need not "fear" communists. Most students have good enough sense not to become communists, as do most professors; but some do not. After all, the professors formerly were students. A university would be irresponsible in permitting the infection of students-not all are immune-by professors known to be infected. ${ }^{10}$ Moreover, the professor who has committed himself to a totalitarian organization is out of place in a university, simply because, unlike his colleagues, he has surrendered his academic freedom.

\section{$\mathrm{V}$ \\ Fellow Travelers}

What about people who may be members of the Communist Party but do not admit as much; and what about sympathizers?

${ }^{17}$ If a man repudiates his party membership, all we need be interested in are his qualifications for future service. I am addressing myself here to those who insist that a continued commitment-or lack of evidence that it has ceased-is no obstacle to continued academic office.

${ }^{18}$ Roman Catholics are sometimes suspected of depending on ecclesiastical instruction in carrying out the duties of public or academic office. It should be noted however that Canon law requires catholies to fulfill the duties of the office they assume, and that American experience with Catholic judges, governors and presidents indicates that there is no parallel with communists, and nothing like a party-line on any scientific questions. Occasionally catholics, of course, may be fanatics-as may vegetarians. A fanatic is not competent to teach even if he is a fanatic liberal. But in considering academic employment we can discriminate in terms of: ( $x$ ) how harmful the belief fanatically pursued is (vegetarianism will hardly be as harmful as communism); (2) whether the fanatical pursuit leads to academically improper behavior, e.g., grading students according to their attitude toward vegetarianism or rating colleagues in these terms. Here political fanaticism seems worse than other kinds.

${ }^{19}$ The argument that communists are needed to teach communism hardly warrants a reply. We do not usually think that you have to have the disease, the virtue, or the vice to be a competent student of it. 
As for suspected members, ordinary means of finding out-interrogation, testimony, and the possible conformity and simultaneity of changes in their views with changes in the party-line-must be used. The relevant issue is whether they hold or change views because of independent research and reflection -or whether the stimulus comes from the party-line.

Refusal to testify as to his actions, beliefs, and commitments certainly is inconsistent with the function of any university professor. A person invoking the fifth amendment to refuse to answer a question by a committee of Congress should not ordinarily be regarded as fit to hold academic office. If he fears genuinely to incriminate himself by answering freely, he can hardly be fit to teach freely. If he does not, he has no right to invoke the fifth amendment, and his misuse certainly disqualifies him. But here, though I should defend the principle, I should like to look at each individual case before making a decision. I can imagine circumstances where the legal right to stand mute is invoked, and the invocation is not inconsistent with academic office. However, the burden of proof is on the unresponsive witness.

Sympathizers are people not fully committed to the Communist Party but willing at times to help it. Since theirs is not a definite commitment, by definition (otherwise they would be crypto-communists) they must be treated according to their actions. If there is cumulative evidence that their sympathies have led them to actions contrary to academic standards, they must be treated accordingly. If their views show a lack of competence, again, action must be taken accordingly. But if neither is the case, the mere outrageousness of their views is not ground for dismissal. ${ }^{20}$

I apologize for discussing communist teachers at such length-it should not be necessary. Unfortunately, it is. The academic community finds it unduly hard to distinguish communists from liberals-and is indignant when outsiders thereupon find it hard to distinguish liberals from communists. Thus, a few years ago a number of major universities insisted-in the name of liberty and academic freedom! -on depriving their students of the opportunity to borrow money from the federal government, because such loans were conditioned on the borrowers stating under oath that they were loyal to the Republic and did not support organizations attempting to overthrow it by unconstitutional means. These universities seriously contended that they had to protect their students from the danger of swearing loyalty to our form of government! Of course, such oaths (which rather than being a novelty, as many people believe, are a tradition in American history) are useless. (So are commencement exercises.) Yet demanding or swearing them is not evilwherefore I can see no positive objection to it. Again, various states have asked professors to swear similar oaths. They have been resisted, at times, by noncommunist professors, whose courage I admire far more than the cause for which it is employed. If it makes legislators feel better that I swear that I am not a

${ }^{20}$ Sidney Hook has brilliantly illuminated this point in his book, HERESY, YES-CONSPIRACY, Nol, op. cit. supra note 7. 
communist and I am not, I certainly can see no reasonable objection to swearing to what is true.

What underlies the resistance of many faculties and administrations is a vague feeling that academic freedom includes the right to be a communist-even if they do not exercise it. For, it is argued, one is not free unless one has a right to hold any intellectual conviction. To be sure. But all freedom is limited by duty. A professor is free to hold any intellectual conviction, even, perhaps, the conviction that he should give up his freedom. But he is not free to give it up-and remain a professor. $\mathrm{He}$ is not free to act on this conviction. The distinction between acts, including organizational commitments and conspiracies, and convictions has a long history in law. Academic freedom cannot be protection for action to surrender it, or for a promise (also an act) to do so. It is time that the academic community accepted John Stuart Mill's dictum: "The principle of freedom cannot require that he should be free not to be free. It is not freedom to be allowed to alienate his freedom." 